\title{
Acute Toxicity of Ethanol Extract of Polygonum pulchrum Blume using Brine Shrimp Lethality Test Method
}

\author{
Asman Sadino ${ }^{1}$, Idin Sahidin ${ }^{1}$, Wahyuni Wahyuni ${ }^{2}$ \\ ${ }^{1}$ Department of Natural Products Chemistry, Faculty of Pharmacy, Halu Oleo University, \\ South East Sulawesi, Indonesia \\ ${ }^{2}$ Department of Pharmacology and Toxicology, Faculty of Pharmacy, Halu Oleo University, \\ South East Sulawesi, Indonesia
}

\begin{abstract}
The potential toxicity effect presents in the medicinal plants is important to be identified for the safety assurance. Accute toxicity study is an initial step in the drug safety assurance test. Thus, the aim of this study is to identify the potential acute toxicity of roots, stems, leaves, and flowers ethanol extracts of bamboo bamboo plants (Polygonum pulchrum Blume). This study used brine shrimp lethality test (BSLT) method. The total number of larvae used in each concentrations in three times replications was 330 larvae. Each group was given consecutively roots, stems, leaves and flowers ethanol extracts of $P$. pulchrum Blume plants with variation concentrations $12.5 \mu \mathrm{g} / \mathrm{ml}, 25 \mu \mathrm{g} / \mathrm{ml}, 50 \mu \mathrm{g} / \mathrm{ml}, 100 \mu \mathrm{g} / \mathrm{ml}, 125 \mu \mathrm{g} / \mathrm{ml}, 250 \mu \mathrm{g} /$ $\mathrm{ml}, 500 \mu \mathrm{g} / \mathrm{ml}, 1000 \mu \mathrm{g} / \mathrm{ml}, 2000 \mu \mathrm{g} / \mathrm{ml}$, and $4000 \mu \mathrm{g} / \mathrm{ml}$. The number of dead larvae after 24 hours treatment were calculated to obtain the mortality percentages and to determine the $\mathrm{LC}_{50}$ value, which were determined by probit analysis using MiniTab application version 17.1.0. Ethanol extract of $P$. pulchrum roots and stems resulted $\mathrm{LC}_{50}$ values of $933.08 \mu \mathrm{g} / \mathrm{ml}$ and $919.58 \mu \mathrm{g} / \mathrm{ml}$, respectively. While the $\mathrm{LC}_{50}$ values of leaves and flowers extracts were $2207.06 \mu \mathrm{g} / \mathrm{ml}$ and $1081.90 \mu \mathrm{g} / \mathrm{ml}$, respectively. In conclusion, $P$. pulchrum Blume roots and stems were classified as toxic according to BLST method, while leaves and flowers were not.
\end{abstract}

Keywords: acute toxicity, brine shrimp lethality test, Polygonum pulchrum Blume

\section{Introduction}

The plants from Polygonum genus have been used empirically as traditional medicines. However, the study report of P. pulchrum B1. is still limited for the potent pharmacology activity. In Korea, Polygonum genus has been used to treat burns, gallstones and hepatitis, 1 and pre-menstruation simptomps. ${ }^{2}$ In Chinese, Polygonum genus plants species such as $P$. orientale L., P. bistorta, $P$. tinctorium $L$, and P.aviculare L. have been used to treat inflammation, dysentery, gout and to improve blood circulation. ${ }^{3}$ The roots of $P$. multiforum Thunb. are used as a tonic

Correspondence: Asman Sadino. Department of Natural Product Chemistry, Faculty of Pharmacy, Halu Oleo University, South East Sulawesi, Indonesia. Email : asman.sadino51@gmail.com 
and anti-aging agent in traditional Chinese medicine and are already registered in Chinese pharmacopoeia. ${ }^{4}$

The potential toxicity effect presents in the medicinal plants is important to be identified for the safety assurance..$^{5}$ Toxicity study is essential as the initial steps in the drug safety assurance. Toxicity study analysis consists of acute, subcronic, and chronic toxicity test.

Brine shrimp lethality test (BSLT) is one of the acute toxicity methods used in determining the toxic effects of a plant. This method is generally used to identify toxicity for natural substances and the method is relatively easy, simple, fast, cheap, and reliable. The plant extract, which classified as toxic can be developed for further analysis as alternative anticancer. While if it is classified non-toxic, the extract can be explored of other properties and pharmacology activities. Therefore, the purpose of this study was to determine the acute toxicity of ethanol extract of $P$. pulchrum Blume.

\section{Methods}

Instruments and materials

The instruments used in this study include rotary vacuum evaporator (Buchi ${ }^{\circledR}$ ), analytical scales (Precisa $\left.{ }^{\circledR}\right)$, blender (philips ${ }^{\circledR}$ ), beaker glass (Pyrex $\left.{ }^{\circledR}\right)$, measuring glass $\left(\right.$ Pyrex $\left.{ }^{\circledR}\right)$, reaction tube (Pyrex $\left.\AA\right)$, stirring rod, vials, measuring flask (Pyrex ${ }^{\circledR}$ ), magnifying glass/lup, mini aquarium, aerator, light bulb (philips $\left.{ }^{\circledR}\right)$. The materials used include ethanol 96\% (Merck®), seawater, DMSO, roots, stems, leaves, and flowers of P. pulchrum Blume

\section{Extraction}

Plant samples were collected from the Faculty of Fisheries and Marine Sciences Halu Oleo Kendari University of Southeast Sulawesi Province. Preparation was done by shredding the previously cleaned sample, then dried and mashed to become powder

A total of $553 \mathrm{~g}$ of roots powder, $1.25 \mathrm{~kg}$ of stems powder, $1.03 \mathrm{~kg}$ of leaves powder, and $1.05 \mathrm{~kg}$ offlowers powder were cold extraction for $3 \times 24$ hours using ethanol $96 \%$, then the filtrate was accommodated and concentrated using a rotary vacuum evaporator.

\section{Toxicity test using BSLT method}

Preparation of $10000 \mu \mathrm{g} / \mathrm{ml}$ stock solution It is weighed 0.5 gram of root, stems, leaves and flowers ethanol extract of P. pulchrum Blume. and dissolved in ethanol, then put into a $50 \mathrm{~mL}$ flask.

\section{Artemi salina Leach eggs hatching}

Artemia salina Leach egg hatching was done in a mini aquarium with two parts of the chamber, one part isolated from light and the other illuminated by light. The insulation was perforated with a diameter of $2 \mathrm{~mm}$. Sea water was put into containers and aerated. A number of Artemia salina Leach eggs were inserted into the space, then the space was closed. The other side was left open and given a lamp to draw Artemia salina Leach which had hatched through a hole. Eggs will hatch approximately after 18 - 24 hours into larvae. Forty eight hour of larvae can be used for toxicity tests. ${ }^{6}$

\section{Sample solutions preparation}

Dilution was performed from stock solution sample of $10000 \mu \mathrm{g} / \mathrm{ml}$ concentration to make variation concentrations of $12.5 \mu \mathrm{g} /$ $\mathrm{ml}, 25 \mu \mathrm{g} / \mathrm{ml}, 50 \mu \mathrm{g} / \mathrm{ml}, 100 \mu \mathrm{g} / \mathrm{ml}, 125 \mu \mathrm{g} /$ $\mathrm{ml}, 250 \mu \mathrm{g} / \mathrm{ml}, 500 \mu \mathrm{g} / \mathrm{ml}, 1000 \mu \mathrm{g} / \mathrm{ml}, 2000$ $\mu \mathrm{g} / \mathrm{ml}$, and $4000 \mu \mathrm{g} / \mathrm{ml}$. Then, each solution was inserted into the vial. Then the vial filled with $10 \mathrm{ml}$ of sea water and added $0.2 \mathrm{ml}$ of DMSO. Vials that had been filled with samples and controls were aerated until dry and no more solvent. Ten healthy (active 
Table 1.The calculation of the LC50 values of each extracts

\begin{tabular}{|c|c|c|c|c|c|}
\hline No. & P. pulchrum Bl. & $\begin{array}{l}\text { Concentration } \\
(\mu \mathrm{g} / \mathrm{ml})\end{array}$ & $\%$ Mortality & $\mathrm{LC}_{50}(\mu \mathrm{g} / \mathrm{ml})$ & Category \\
\hline 1 & Roots & $\begin{array}{c}0 \\
12,5 \\
25 \\
50 \\
100 \\
125 \\
250 \\
500 \\
1000 \\
2000 \\
4000 \\
\end{array}$ & $\begin{array}{c}0 \\
30.0 \\
30.0 \\
33.3 \\
40.0 \\
50.0 \\
50.0 \\
60.0 \\
70.0 \\
73.3 \\
76.6 \\
\end{array}$ & 933.08 & Toxic \\
\hline 2 & Stems & $\begin{array}{c}0 \\
12.5 \\
25 \\
50 \\
100 \\
125 \\
250 \\
500 \\
1000 \\
2000 \\
4000 \\
\end{array}$ & $\begin{array}{c}0 \\
76.6 \\
73.3 \\
66.6 \\
60.0 \\
53.3 \\
46.6 \\
43.3 \\
40.0 \\
33.3 \\
26.6 \\
\end{array}$ & 919.58 & Toxic \\
\hline 3 & Leaves & $\begin{array}{c}0 \\
12.5 \\
25 \\
50 \\
100 \\
125 \\
250 \\
500 \\
1000 \\
2000 \\
4000 \\
\end{array}$ & $\begin{array}{c}0 \\
60.0 \\
56.6 \\
53.3 \\
43.3 \\
33.3 \\
33.3 \\
30.0 \\
23.3 \\
16.6 \\
13.3 \\
\end{array}$ & 2207.06 & Non Toxic \\
\hline 4 & Flowers & $\begin{array}{c}0 \\
12.5 \\
25 \\
50 \\
100 \\
125 \\
250 \\
500 \\
1000 \\
2000 \\
4000 \\
\end{array}$ & $\begin{array}{c}0 \\
33.3 \\
33.3 \\
36.6 \\
50.0 \\
53.3 \\
53.3 \\
56.6 \\
60.0 \\
63.3 \\
70.0 \\
\end{array}$ & 1081.90 & Non Toxic \\
\hline
\end{tabular}


moves) Artemia salina Leach aged for 48 hours were selected randomly, then inserted into the vial containing the sample. The standard criteria for measuring shrimp larvae mortality is if the shrimp larvae do not show any movement for several seconds during observation. The dead larvae was manually calculated by observing the larvae inside the vial with the magnifying glass or loop. Vials were placed under the lamps for 24 hours and measured the number of dead larvae of Artemia salina Leach.

\section{Determination of \% mortality}

Determination of the percent mortality was performed after 24 hours of treatment using the following formula. ${ }^{7,8}$

$$
\% \text { Mortality }=\frac{\text { Amounts of A. salina dead larvae (test-control) }}{\text { The total amounts of larvae tested }} \times 100 \%
$$

\section{Results and Discussion}

BSLT was chosen because it is easy, fast, cheap and reliable. Toxicity test was examined thre times. All of the extracts in varied concentrationts used ten shrimp larvae of Artemia salina Leach aged 48 hours.

The number of deaths of Artemia salina Leach larvae in each vial in various concentrations of root, stem, and flower ethanol extracts of P. pulchrum Blume were shown in Table 1. A compound is categorized as toxic if its $\mathrm{LC}_{50}$ value $<1000 \mu \mathrm{g} / \mathrm{ml}^{7,8}$

Based on the results in the Table 1. it can be seen that the toxicity of the BSLT test results from root, stems, leaves and flowersethanol extract of P. pulchrum Bl. showed that roots and stems were toxic with $\mathrm{LC}_{50}$ values of $933.08 \mu \mathrm{g} / \mathrm{ml}$ and $919.58 \mu \mathrm{g} / \mathrm{ml}$ respectively, while leaves and flowers were classiefied as non-toxic with the LC50 values of 2207.06 $\mu \mathrm{g} / \mathrm{ml}$ and $1081.90 \mu \mathrm{g} / \mathrm{ml}$, respectively.

The toxicity of $\mathrm{P}$. pulchrum plant is predicted to be correlated with content of secondary metabolites. The mechanism of action of alkaloids and flavonoid compounds, which can inhibit the larvae feeding power is because the secondary metabolites compounds act as a stomach poisoning for the larvae. Therefore, when the compounds enter the larvae body, the compounds can cause a disturbance in its digestive system and can inhibit the taste receptors in the mouth region of the larvae. This resulting the larvae fails to get the taste stimulus and can not be able to recognize the food and cause the larvae die for starvation. Saponins group compounds can also bind to the oxygen contained in the water so that the oxygen levels in the water decreased and the larvae will die cause the lack of oxygen. ${ }^{10,11}$

\section{Conclusion}

In conclusion, $P$. pulchrum Blume roots and stems were classified as toxic according to BLST method, while leaves and flowers were not.

\section{References}

1. Ban S, Kwon Y, Pandit S, Lee Y, Yi H, and Jeon J. Effects of a bio-assay guided fraction from Polygonum cuspidatum root on the viability, acid production and glucosyltranferase ofmutans Streptococci. Fitoterapia. 2010;81(1):30-34.

2. Choudhary RK, Oh S, and Lee J. An ethnomedicinal inventory of knotweeds of Indian Himalaya. Journal of Medicinal Plants Research. 2011;5(10):2095-2103.

3. Wang K, Zhang Y, and Yang C.Antioxidant phenolic compounds from rhizomes of Polygonum paleaceum. Journal of Ethnopharmacology. 2005;96:483-487. . 
4. China Pharmacopoeia Committee. Pharmacopoeia Of The People's Republic Of China, The First Division. Beijing: China Chemi Press; 2010.

5. Ekor M. The growing use of herbal medicines: issues relating to adverse reactions and challenges in monitoring safety. Frontiers in Pharmacology. 2013;4:177.

6. Da Costa JGM, Campos AR, Brito SA, Pereira CKB, Souza EO, Rodrigues FFG. Biological screening of araripe basin medicinal plants using Artemia salina Leach and pathogenic bacteria. Pharmacognosy Magazine. 2010;6(24):331-334.

7. Pour BM, Sasidharan S. In vivo toxicity study of Lantana camara. Asian Pacific Journal of Tropical Biomedicine. 2011;1(3):230-232.

8. Sahgal G, Ramanathan S, Sasidharan $\mathrm{S}$, Mordi MN, Ismail S, Mansor SM. Brine shrimp lethality and acute oral toxicity studies on Swietenia mahagoni (Linn.) Jacq. seed methanolic extract. Pharmacognosy Research. 2010;2(4):215220.

9. Coe FG, Parikh DM, and Johnson
CA. Alkaloid presence and brine shimp (Artemia salina) bioassay of medicinal species of Eastern Nicaragua. Pharmaceutical Biology. 2010;48(4):43945.

10. Saleh-e-In MM, Sultana N, Hossain MN, Hasan S, Islam MR. Pharmacological effects of the phytochemicals of Anethum sowa L.rootextracts. BMCComplementary and Alternative Medicine. 2016;16:464.

11. Procópio TF, Fernandes KM, Pontual $\mathrm{EV}$, et al. Schinus terebinthifolius leaf extract causes midgut damage, interfering with survival and development of Aedes aegypti larvae. Soberón $\mathrm{M}$, ed. PLoS ONE. 2015;10(5):e 0126612. 